In the particles of silica placed upon the glass slide, when they were completely separated from each other, the outlines of the individual diatoms were sharply and distinctly defined. On the other hand, when the physical action of ebullition with nitric acid was not sufficient for the complete separation of the particles of the epidermal shield, there was observed a marvellous interlacing of the various forms, showing that they were conveyed by the sap-cells directly to the section of the plant where they were destined to complete its structure. I have examined several specimens of straw, taken at random in the market: the silica in each specimen consisted of plates, very thin and truncated at the corners.

The result of these investigations shows the necessity of finely divided silica in the soil, so minute as to be capable of passing with facility through the sap-cells; secondly, that simple or compound silicates are useless as fertilizing agents, either natural or artificially prepared. We have no valid reason for forming any theory that vegetation can, through any known chemical law, separate the elements or their compounds from combinations so positive in their character.

In this case we have a practical result, capable of being verified at any stage of growth of a plant, produced by the application of silica to the soil in the form of certain well-defined microscopic organisms ; for, finding these in the ash to the exclusion of other particles of silica, they seem to be more acceptable for the plantstructure. Free silica is hence the ouly condition in which it can enter the plant.

I look upon this discovery as leading agricultural investigations in a new direction; and it must eventually change many of the views expressed and accepted by scientists.

Every precaution was used in having all the material thoroughly cleansed, with a view both to accuracy and to removing suspicions that these microscopic forms were the result of dust-showers.Silliman's American Journal, May 1876.

Washington University, Medical Department. Baltimore, Md., February 1876.

\title{
On Fish of the Ceratodus-group existing in the River Fitzroy,
} South Australia. By M. PaUL Gervais.

M. Paul Gervais announces that he has received from M. Francis de Castelnau, French Consul at Melbourne, an intimation of the existence in the river Fitzroy of a new form of fish allied to Ceratodus. It presents the principal characters of the species from the river Burnett, to which Messrs. Krefft and Günther have given the name of Ceratodus Forsteri, but differs from them sufficiently to lead M. de Castelnau to regard it as forming a distinct genus. He gives the name of Neoceratodus to this genus, and calls the species N. Blanchardi.-Comptes Rendus, May 1, 1876, p. 1034. 


\section{$2 \mathrm{BHL}$ Biodiversity Heritage Library}

Gervais, Paul. 1876. "On fish of the Ceratodus-group existing in the River Fitzroy, South Australia." The Annals and magazine of natural history; zoology, botany, and geology 17, 486-486. https://doi.org/10.1080/00222937608681999.

View This Item Online: https://www.biodiversitylibrary.org/item/63494

DOI: https://doi.org/10.1080/00222937608681999

Permalink: https://www.biodiversitylibrary.org/partpdf/59599

\section{Holding Institution}

University of Toronto - Gerstein Science Information Centre

\section{Sponsored by}

University of Toronto

\section{Copyright \& Reuse}

Copyright Status: NOT_IN_COPYRIGHT

This document was created from content at the Biodiversity Heritage Library, the world's largest open access digital library for biodiversity literature and archives. Visit BHL at https://www.biodiversitylibrary.org. 